\title{
The Confusion and Countermeasures of Green Accounting in China
}

\author{
Xinyang Kan, Qingjun Meng \\ Business College of Hohai University, Hohai University, Nanjing, China \\ Email: 1186069051@qq.com
}

Received 14 July 2015; accepted 10 August 2015; published 13 August 2015

Copyright (C) 2015 by authors and Scientific Research Publishing Inc.

This work is licensed under the Creative Commons Attribution International License (CC BY). http://creativecommons.org/licenses/by/4.0/

c) (i) Open Access

\begin{abstract}
Green accounting is a new accounting field whose main function is to balance the development on both economy and environment through effective value management and combining accounting and environmental economy. Owing to the lack of relative regulation and the absence of governmental supervisory, there are some obstructions impeding its practice. In order to solve those problems, relatively well-established laws, governmental intervention and training young accountants are required in this process.
\end{abstract}

\section{Keywords}

\section{Green Accounting, Environmental Protection, Economic Benefits, Sustainable Development}

\section{The General Analysis on Green Accounting}

The main purpose of Green Accounting is to realize the combination of economic development and environmental protection by effective value management and integrating accounting and environmental economy. Specifically, Green Accounting is a newly-born subject that analyzes the environmental effectiveness and the effect of the environmental activities on the enterprise's financial results. It is relied on currency as the main unit of measurement, based on relevant laws and regulations, measuring and recording the cost of environmental pollution, environmental control, environmental development costs, maintenance and development of the formation of the benefits to the environment at the same time reasonable measurement and report.

The purpose of Green Accounting is to combine accounting with environmental economics, through effective value management, achieve the goal of coordinating economic development and environmental protection. In 1992, the world environment and development conference passed four programmatic documents on protection of the environment, from that time, environmental issues started to be concerned. In 1999, the United Nations discussed the announcement on the position of the environmental accounting and reporting, and formed a com- 
plete system of international environmental accounting and report guidelines [1]. Governments have set up their own system of environmental accounting. In China, the government established the "green accounting committee” in March 2001 [2]. In June 2001, approved by the ministry of finance, accounting society of China established the professional committee of the seventh-environmental accounting professional committee, China's green accounting research turning into a new stage.

Compared with developed countries which had begun to research and implement green accounting in the early 1970s, China is relatively late in the green accounting theory research and practical exploration. In the process of implementation of green accounting, most of the enterprises in China are still passive to bear environmental protection responsibility, or escape from bearing it. In this case, it is of great significance to find the solution to the problems occurring during the implementation of green accounting and push forwards the movement. It is beneficial to the sustainable development, to suppress the ecological and resource crisis, and to put the resourcesaving and environmental protection policy into effect by combining the fiscal business accounting mode and the operation result reflection mode together, which contains the environmental result causing by the gross social product, exchanging, consuming, and product subject into fiscal business accounting.

\section{Literature and Research Review}

Ge Jiashu (1992) once said [3], green accounting was a hot topic in western accounting field in the 1990s. However, because of the weakness of green accounting theory researching, so far, the development of green accounting is quite slow. To get rid of weakness of green accounting theory, it is necessary to build up the green accounting theory structure as soon as possible. This view has played a pioneering role in widening the green accounting research field. In 2001, at the nine session of Chinese People's Political Consultative Conference (CPPCC) four times meeting, Zhi Gong Party put forward the Suggestions for a green accounting system of which was spoken highly by the ministry of finance. The proposals, the implement of relevant suggestions, and founded the environmental accounting professional committee, contributed to the country's first environmental accounting professional meeting.

Yang Zhen (2013) [4] first to analyze the current situation of the development of China's green accounting: the implementation of green accounting in the presence of people in the government of insufficient attention to green accounting, green accounting theory and practical operation is still immature, green accounting-related issues such as weak human resources. And then put forward to improve awareness, build a reasonable green accounting system, perfect the relevant legal framework for green accounting system; Liu Yaqin (2013) [5] contrasted green accounting and traditional accounting differences by studying the basic principles and fundamental elements, Green accounting can respond to traditional accounting can’t completely supervision and management activities to supplement, the increase in capital measurement of defects, emphasizing the development of green accounting is conducive to the sustainable development of enterprises, attract foreign investment, accounting reform and development. Li Lihua (2011) [6] analyzed of the existing accounting system and green accounting is not adaptable, noting that the process of implementation of green accounting should follow the long-term and gradual, flexible start and borders, systematic and win-win principle.

\section{The Difficulties in the Green Accounting Implementation}

\subsection{Lack of Relative Theory}

Due to the diversity of green accounting system and the accounting of complicated objects, especially the measurement process which has not yet been breakthrough, all those factors make the green accounting lack practice of combining the theory fulcrum. Therefore, the accounting theory research should be strengthened, and actively be explored. Because of its lack of generally accepted accounting hypothesis, accounting standards and accounting object, accounting methods of green accounting is controversial [7].

\subsection{Relevant Laws and Regulations Not Perfect}

China has not yet formed a special green accounting laws and regulations, the enterprise accounting system and information disclosure of the relevant laws and regulations are rarely involving environmental problems [4]. In the accounting practice, there has been no system of green accounting and information disclosure system and specifications. Because of the lack of mandatory rules, the stakeholders' demand for corporate disclosure of en- 
vironmental information is not very strong [8]. What's more, enterprise environmental information disclosure has just started, and as a result, it the lack of relevant specification.

\subsection{Absence of Governmental Effective Supervision Measures}

At present, China implements one-year-end audit of corporate annual reports [4], instead of the green accounting one. Therefore, it lacks substantial social supervision [9]. In the absence of social supervision, it is difficult to implement green accounting when the enterprise only rely on self-discipline.

\subsection{Entrepreneurs' Myopia towards Environmental Protection}

Since the reform and opening up our country, in order to support the rapid economic development, more emphasis on community growth in the number of GDP, ignoring environmental pollution and other issues. Which easily lead to many of our businesses green and environmental sense of responsibility is not strong, Highlight economy while lighten environment and "Treatment after pollution", such kinds of thoughts are commonplace in China. Enterprises often simply focus on interests, lightening viewpoint of environmental protection and the construction of green accounting [10]. Among them, the enterprise to the environmental protection problem exists short-sighted behavior.

\subsection{Lack of Green Accounting Talents}

Green accounting belongs to an emerging field in our country. China's green accounting started relatively late, and its development progress is rather slowly. The absence of the training in related industries [11], and the lack of formed theory system cause the shortage of competent green accounting personnel [12]. And there is a ridiculous situation that the need and demand of green accounting talents cannot match each other. People in China are ignorant of green consciousness. The damage of social public facilities, and overusing public places are also the manifestations of the weak sense of green accounting.

\section{Solution to the Problem of Difficulty in Green Accounting}

\subsection{To Build a Reasonable System of Green Accounting}

China's green accounting system should do the followings: firstly, redefine the accounting objectives and determine the goal in order to achieve sustainable development, realizing economic benefit, environmental benefit and social benefit balanced development; secondly, for the traditional accounting hypothesis, accounting elements of the accounting system, accounting method, the system should be reserved to the greatest extent, to compatible with the existing accounting system, to reduce the resistance of green accounting system implementation [4]; then, separate the accounting subjects from the economic factors in the account settings in order to the accounting report disclosure of environmental information; in the accounting identity subjects such as, increasing the income of environmental assets, environmental Objective in order to strengthen comprehensive green accounting information disclosure; finally, in accordance with the unified caliber, assemble a comprehensive green accounting information.

\subsection{Develop and Perfect the Relevant Legal Framework for Green Accounting System}

In order to promote green accounting in China as soon as possible, measures shall be taken to strengthen the construction of the legal system of green accounting. Green accounting is a complicated system, including not only economic issues, environmental and social problems, but also the problem of time and space. So the systemic principle shall be highlighted. Green accounting and supervision which have been listed in the "accounting law", are determined its status and role in the form of law [13]. Enterprise environmental consequences of the accounting system, can through the legitimacy of the financial statements reflect the enterprise environment matters and authenticity, reflect the equality.

\subsection{Improve the Social Responsibility Assessment System, Strengthen the Supervision of Green Accounting}

Green accounting information should be provided by the fully reveal the enterprise social responsibility for en- 
vironmental protection. Evaluation of enterprise should be matched with enterprise social benefits, social cost and social profits for the standard, stand in the perspective of social enterprises in all aspects of performance, in order to maintain social resources and environment, national macroeconomic regulation and control [14]. Can require companies to report environment should be as a part of the financial report, submit together with the annual financial report, and report released through the Internet business environment, increased the transparency of corporate environmental information report, strengthen supervision, and examination of enterprises. All parties in society. Supervised by the government on the one hand [15]; on the other hand can also be commissioned by the government to participate in supervision of an impartial third party, such as accounting firms and other commission.

\subsection{Establish Enterprises' Environmental Responsibility}

Enterprises should avoid saving costs at the expense of the environmental behavior, setting up both social benefits and economic benefits. In order to better protect the environment, can from the following two aspects: 1) extensive discussions on the question of environmental protection and resource saving and training, strengthening the consciousness of enterprise environmental protection and resource conservation, promote green production and the continuous application of clean energy, environmental protection technology, encourage enterprises to establish the development of green accounting [16]. 2) according to the actual situation of each enterprise, choose a few should focus on strengthening the environmental protection consciousness of corporate finance as a pilot, from point to surface, gradually implement green accounting.

\subsection{Promote Green Accounting Education System}

Set up a corresponding system of rewards and punishments, environmental improvements to play an active role in promoting enterprise offer certain substances or reward policy, to destroy the environment of the enterprise to give punishment, to ensure the fair. To improve the public environmental consciousness, forming of the supervision by public opinion of the enterprise. Universities should strengthen environmental agencies, businesses work together to cultivate green accounting personnel [17]. Newspapers, radio, Internet and other obligation to strengthen propaganda, promote the concept of Green Accounting.

\section{Conclusion}

The importance of the implementation of green accounting increases concern of the community. Due to incomplete green accounting standards, in the face of enterprise short-sighted about environmental problem lack of government supervision, lack of green accounting professionals, there are difficulties in green accounting implementation. As the country continues to be the rule of law, especially for green accounting regulations gradually perfect, enterprise changing management idea, and perfect the social responsibility appraisal system, strengthen the supervision of social parties on green accounting. Will eventually solve the difficulties in green accounting for China limited will be efficient use of natural resources, ecological environment will be improved in our country, the economy will be more healthy development, the society will become more harmonious.

\section{References}

[1] Li, Y.H. (2013) Green Accounting and Its Application. Chinese \& Foreign Entrepreneurs, 419, 89-91.

[2] Xiao, J. (2013) Thinking of the Green Accounting. Industrial \& Science Tribune, 12, 117-118.

[3] Ge, J.S. and Li, R.S. (1992) Western Accounting Theory Is a New Trend in the Nineties, the Green Accounting Theory. Accounting Research, 5, 1-6.

[4] Yang, Z. (2013) Chinese Green Accounting Situation and Countermeasures. Chinese \& Foreign Entrepreneurs, 435, 192.

[5] Liu, Y.Q. and Zhu, X.L. (2013) The Development of the Green Accounting in Chinese Enterprises. Management \& Technolosy of SME, 28, 72.

[6] Li, L.H. (2011) Discussion on the Green Accounting in China. Journal of Suzhou Institute of Education, 14, $28-31$.

[7] Chen, N.D., Wang, X.B. and Zou, L.Y. (2006) Discussion of Green Accounting Framework to Build in China. Science Technology and Industry, 6, 59-62.

[8] Guo, J.L. (2007) Discussion on the Green Accounting. Liaoning Urban and Rural Environmental Science \& Technol- 
ogy, 27, 60-61, 72.

[9] Xie, X.F. (2010) Carbon Accounting on the Influence and Meaning of the Enterprise Environment Accounting. Accountant, 2, 18-19.

[10] Mao, Y.Q. (2013) Construction of Green Accounting Theory System of Private Enterprise. Economic Research Guide, 24, 188-189.

[11] Yuan, Z.S. (2011) Green Accounting Application Research. Modern Economic Information, 5, 117.

[12] Wang, W. (2015) Enterprise Green Accounting Information Disclosure Issues and Solutions. Journal of Hezhou University, 31, 103-106.

[13] Zhou, X.F. (2007) On Conditions for Sustainable Development under the Implementation of Green Accounting. Contemporary Economics, 4, 119-120.

[14] Chen, G. and Li, G.L. (2013) Discussion on Some Issues of Green Accounting. Modern Economic Information, 8, 280281.

[15] Guo, R.N. (2012) Strengthen the Government Function in Green Accounting. Friends of Accounting, 11, 49-50.

[16] Wang, X.T. (2014) Necessity and Feasibility of Green Accounting Development. Business, 5, 112.

[17] Yao, J.H. (2012) Discussion on Green Accounting Theory. Shaanxi Journal of Agricultural, 3, 199-201. 